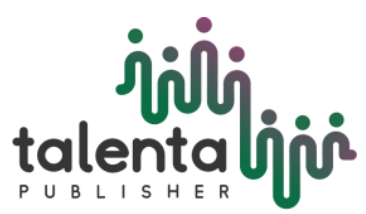

\title{
Partial Least Square (PLS) Analysis: The Relationship of Production Management and Business Analysis of Goat Farm in Deli Tua Village, Namorambe District, North Sumatera, Indonesia
}

\author{
Mudhita Zikkrullah Ritonga ${ }^{1}$ and Risdawati Br. Ginting ${ }^{2}$ \\ ${ }^{1}$ Faculty of Veterinary Medicine, Universitas Syiah Kuala, Banda Aceh, Indonesia \\ ${ }^{2}$ Faculty of Science and Technology, Universitas Pembangunan Panca Budi, Medan, Indonesia
}

\begin{abstract}
Goat farm business provides income both for farmers and the community. Goat farming is very potential because the goats have adult sex and adult body and the length of goat breeding is very short compared to other ruminants. The existence of goat livestock business can create jobs and business that it can help the people's economy. This study aims to identify the relationship between production management and business analysis of goat farm in Deli Tua Village, Namorambe District, North Sumatera, Indonesia. This study used data from nine respondents who own 25-50 goats that were determined by purposive sampling. The data were analyzed by using Partial Least Square (PLS) method shows a significant relationship between production management and business analysis. Keeping management is production management is a indicators of production management which gives a very influential effect on business analysis.
\end{abstract}

Keywords: business analysis, goat farm in Deli Tua, production analysis

Received 18 January 2019| Revised 22 March 2019| Accepted 03 June 2019

\section{Introduction}

Farm business prospects oriented to superior commodity and specific will have a significant role as supply of knowledge and livestock technology. They will provide agricultural development in the future with advanced, and efficient characterized by the ability to improve farmers' welfare. They will also support the development of related sectors as well as national economy in general [1]. Farm development is part of the agricultural development that supports provision of nutritious and competitive animal feed and creates job opportunities in the field of farm agribusiness [2].

\footnotetext{
*Corresponding author at: Faculty of Veterinary Medicine, Universitas Syiah Kuala, Jl. Tgk. Hasan Krueng Kalee No.3, Kopelma Darussalam, Syiah Kuala, Kota Banda Aceh, Aceh, Indonesia

E-mail address: mudhitaritongavet@gmail.com
} 
One of the farms business to develop is goat farm. Goats are livestock with easy keeping. From the commercial development point of view, it is a very potential business since the sexual adult age, bodily age, and pregnancy duration of goats are very short compared to other ruminants [3]. The goat farm business profile in primary business sector shows that such business provides relatively good profit with the I/O ratio value of 1.39 for fattening [4]. Goat farm does not only create job and business opportunities, but also income and revenue [5]. Goat farm is a significant component in community agricultural business since small-scale goat care can help the community's economy through utilization of natural resources available nearby.

Kecamatan Namorambe is one of the district in Deli Serdang that has which has a decline in the number of goat population. The goat population declined from around 11.085 in 2017 to 5.323 in 2018 [6]. The goat farm population is spread across 36 villages and Deli Tua is one of them. This village has potentials in developing goat farm with its abundant source of forage. Even though goat keeping is a side business, it is expected to help enhance the income of goat farm business so as to increase famers' welfare [7]. Based on the explanation above, research is needed to identify the relationship between production management system and goat farm feasibility analysis in Deli Tua Village, Namorambe District by using Partial Least Square (PLS) Analysis.

\section{Methods}

This is a direct observation survey study by interview based on prepared questionnaire. The population of this study is goat farmers in Deli Tua Village, Namorambe District with goat farm business as the study's object. Deli Tua village is a village in Namorambe district that has a high population of goats compared with other village. Aside from being a goat farmer, another requirement for respondents is owning a minimum of 25 goats at the time of study, which narrowed it down to nine respondents/farmers. The study was conducted at goat farm business in Deli Tua Village, Namorambe District in April 2018.

Data collection was carried out through observation method, namely by systematically record the observation results of events investigated during the study [8]. The data collection procedure used in this study is: 1) Interview, a method used to obtain primary data to identify quantitative aspects through a structured and prepared questionnaire, 2) Document Study, data collection done by checking and taking notes of documents or records related to the study as supporting data, and 3) Focus Group Discussion (FGD), a group discussion to generate qualitative data and explore specific issues.

The collected data were processed and analyzed about the relationship between production management variable such as breeding management (X1), keeping management (X2), cage management (X3), feed management (X4) and health management (X5) as known independent 
variables with business analysis (Y1) and financial analysis (Y2) as known dependent variables.

The next analysis step used Partial Least Square (PLS) method, a Structural Equation Modelling (SEM) alternative method with variance as the basis which can simultaneously test the measurement model at once structural model testing.

\section{Result and Discussion}

Bootstrapping result for T-statistics value of keeping management-business analysis relation is at 2.290. This value indicates that the relationship in question is significant (>1.96). As for the original sample estimate, the value is positive at 0.630 , meaning that the keeping managementbusiness analysis relationship tends to be positive (Table 1).

Table 1. Partial Least Square (PLS) Analysis Result of Laten Variable

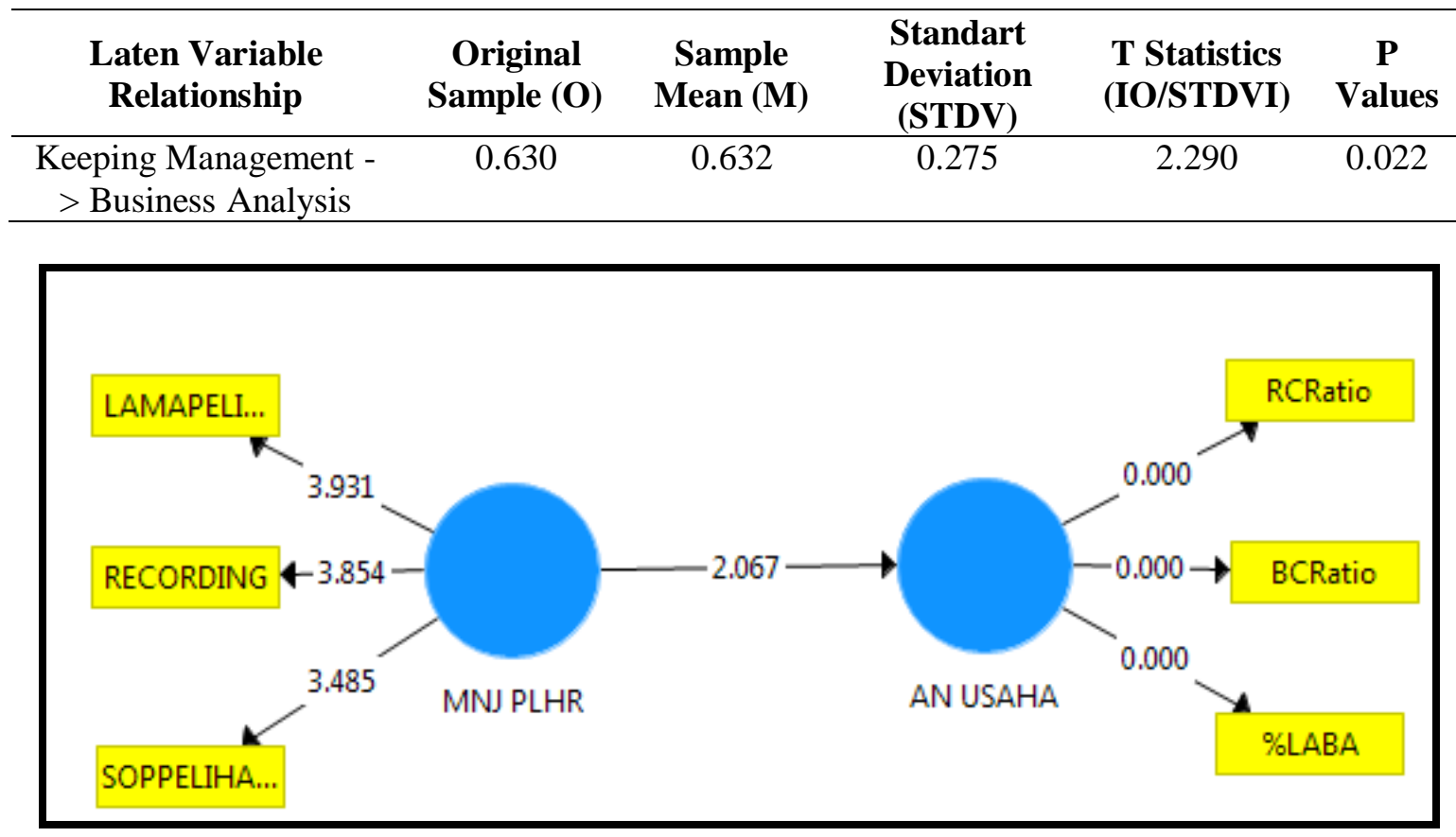

Figure 1. Diagram of Partial Least Square (PLS) Analysis Result Source: Output SmartPLS

Table 2. Partial Least Square (PLS) Analysis of Variable Indicator

\begin{tabular}{cccccc}
\hline $\begin{array}{c}\text { Relationship of } \\
\text { Indicator Variable and } \\
\text { Variable Indicator }\end{array}$ & $\begin{array}{c}\text { Original } \\
\text { Sample (O) }\end{array}$ & $\begin{array}{c}\text { Sample } \\
\text { Mean (M) }\end{array}$ & $\begin{array}{c}\text { Standart } \\
\text { Deviation } \\
\text { (STDV) }\end{array}$ & $\begin{array}{c}\text { T Statistics } \\
\text { (IO/STDVI) }\end{array}$ & $\begin{array}{c}\text { P } \\
\text { Values }\end{array}$ \\
\hline $\begin{array}{c}\text { Percentage Benefit <- } \\
\text { Business Analysis }\end{array}$ & 1.000 & 1.000 & 0.000 & & \\
$\begin{array}{c}\text { BC RATIO <- Business } \\
\quad \text { Analysis }\end{array}$ & 1.000 & 1.000 & 0.000 & & \\
$\begin{array}{c}\text { Keeping Duration <- } \\
\text { Keeping Management }\end{array}$ & 0.874 & 0.823 & 0.222 & 3.932 & 0.000 \\
$\begin{array}{c}\text { RCRATIO <- Business } \\
\quad \text { Analysis }\end{array}$ & 1.000 & 1.000 & 0.000 & & \\
$\quad \begin{array}{l}\text { RECORDING <- } \\
\text { Keeping Management } \\
\quad \text { Keeping SOP <- }\end{array}$ & 0.845 & 0.805 & 0.219 & 3.854 & 0.000 \\
Keeping Management & 0.861 & 0.785 & 0.247 & 3.485 & 0.001 \\
\hline
\end{tabular}


Table 2 the original sample estimate value on three variables of keeping management indicators is 0.874 for keeping duration, 0.845 for recording and 0.861 for keeping SOP. Those data show that highest indicator variable that influences keeping management-business analysis relation is keeping duration. Those two variables have higher influence as indicator variables for keeping management rather than other indicator variables. Feed and water place cleaning is carried out every day by washing before they are reused [4]. Uncleaned feed and water place will become a medium for germs and fungus to live, leading to diseases infecting the livestock. Feed and water place cleaning is done along with cage cleaning. Goats should be bathed at least once in two weeks in the morning in sunny day so as to make the goats dry fast [4]. Goats with dirty body are possibly where many kinds of parasite and microbes grow, develop, and eventually cause various diseases [4].

Goats' cleanliness indirectly has impacts on the increased production [4]. Goat farmers in Deli Tua Village of Namorambe District keep their goats five to six months (52\%), seven to eight months (40\%) and three to four months (8\%) depending on Qurban Holiday. Goats to be fattened for five months should be bought and kept since they were seven-month age, while those to be fattened for seven months should be bought and kept since five-month age. In Indonesia, goats are generally slaughtered at young age. Goats slaughtered at young age are more preferred since their meat is tender and good-smelling [9]. Farmers keep their goats for 57 months as an adjustment to the market demand in general. The best time to slaughter goats is when they are a maximum of 24 months old. According to [10], goats are most responsive to feed since adolescent phase at 7-8 months up until 1.5 years old.

\section{Conclusion}

The conclusion of the study is there is a strong relationship between production management and goat farm business analysis in Candi District, Sidoarjo Regency. The main production management component influencing the business analysis is keeping management.

\section{Acknowledgement}

Gratitude sent for Allah SWT, the God Almighty and Prophet Muhammad SAW, as well as a thank you for the Dean, Head of Study Program, and Lecturers of Veterinary Medicine Faculty Universitas Siah Kuala, Banda Aceh. 


\section{REFERENCES}

[1] M. Rangkuti, A. Setiadi, Solich and A. Rusjat. "Pedoman Praktis Beternak KambingDomba sebagai Ternak Potong". Puslitbangnak, Balai Penelitian dan Pengembangan Pertanian. Departemen Pertanian, Bogor, 2006.

[2] S. Pakage, "Analisis pendapatan peternak kambing di Kota Malang", Jurnal Ilmu Peternakan, vol. 3, no. 2, pp. 51-57, 2008.

[3] Sundari and K. Efendi, "Analisis Pendapatan dan kelayakan usaha peternak kambing peranakan etawah di Kecamatan Girimulyo Kabupaten Kulonprogo", Jurnal AgriSains, vol. 1, no. 1, 2010.

[4] Sodiq and Abidin. Meningkatkan Produksi Susu Kambing Peranakan Ettawa. Jakarta Selatan: Agromedia Pustaka, 2008.

[5] I. K. Sutama. Teknologi Reproduksi Ternak Kambing. Makalah disampaikan pada Temu Aplikasi Paket Teknologi Pertanian, BPTP Nusa Tenggara Barat, 2004.

[6] Badan Pusat Statistik Kabupaten Deli Serdang. Deli Serdang dalam Angka. 2018.

[7] Zulfanita, "Kajian analisis usaha ternak kambing di Desa Lubangsampang Kecamatan Pituruh Kabupaten Purworejo," Mediagro Jurnal Ilmu-Ilmu Pertanian, vol. 7, no. 2, pp. 61-68, 2011.

[8] Marzuki. Metode Riset. Yogyakarta: BPFE-UII, 2000.

[9] Mulyana and Sarwono. Penggemukan Kambing Potong. Jakarta: Penebar Swadaya, 2007

[10] B. Sarwono. Beternak Kambing Unggul. Jakarta: Penebar Swadaya, 2007. 